\title{
Effect of climate change on sowing and harvest dates of spring barley and maize in Poland**
}

\author{
Pawet Marcinkowski $i^{1}$ and Mikotaj Piniewski ${ }^{1,2}$ \\ ${ }^{1}$ Faculty of Civil and Environmental Engineering, Department of Hydraulic Engineering, Warsaw University of Life Sciences, \\ Nowoursynowska 166, 02-787 Warsaw, Poland \\ ${ }^{2}$ Potsdam Institute for Climate Impact Research, Telegraphenberg A 31, Potsdam 14473, Germany
}

Received August 8, 2017; accepted January 19, 2018

\begin{abstract}
Climate change and projected temperature increase is recognised to have significant impact on agricultural production and crop phenology. This study evaluated the climate change impact on sowing and harvest dates of spring barley and maize in the boundaries of two largest catchments in Poland the Vistula and the Odra. For this purpose, an agro-hydrological Soil and Water Assessment Tool has been used, driven by climate forcing data provided within the Coordinated Downscaling Experiment - European Domain experiment projected to the year 2100 under two representative concentration pathways: 4.5 and 8.5. The projected warmer climate significantly affected the potential scheduling of agricultural practices, accelerating the occurrence of sowing and harvest dates. The rate of acceleration was dependent on the time horizon and representative concentration pathways scenario. In general, the rate of sowing/harvest advance was accelerating in time and, also from representative concentration pathways 4.5 to 8.5 , reaching 23 days for spring barley and 30 days for maize (ensemble mean for the far future under representative concentration pathways 8.5).

Keyw ords: SWAT and EPIC models, phenology, heat units, temperature
\end{abstract}

\section{INTRODUCTION}

Climate change is widely recognised to have substantial impact on water quality (Glavan et al., 2015; Marcinkowski et al., 2017) and various economic sectors, including agriculture, which is highly vulnerable to temperature and precipitation changes (Albiac et al., 2017; Gil et al., 2017; Møller et al., 2017). According to International Phenology Gardens (IPG), there is an average trend in Europe for particular phases to advance by approximately 2 days/decade

\footnotetext{
*Corresponding author e-mail: p.marcinkowski@levis.sggw.pl **This work was supported by the project CHASE-PL (Climate change impact assessment for selected sectors in Poland) of the Polish-Norwegian Research Programme operated by the National Centre for Research and Development (NCBiR) under the Norwegian Financial Mechanism 2009-2014, in the frame of Project Contract No. Pol Nor/200799/90/2014.
}

from 1959 to 1996 (Menzel, 2000, 2006). Crop phenology is assumed to be one of the most important features involved in the final yield assessment and the adaptation of crops to the changing environmental conditions. The assessment of cropping systems response to a warmer climate plays a crucial role in the evaluation of future agricultural production potential, and the investigation of crop phenology response is a key stage for a better formulation of adaptation policies (Duchene and Schneider, 2005; Lipiec et al., 2013; Sadras and Monzon, 2006; Wolfe et al., 2005).

The occurrence of consecutive crop phenological phases may be assessed using numerical models of crop growth (Ma et al., 2012; Olesen and Bindi, 2002). In general, three groups of phenological models can be distinguished i.e. theoretical, statistical and mechanistic (Kozyra, 2013). The latter have become the most popular due to their usefulness for quantitative assessments of different environmental factors (e.g. temperature and precipitation change) impact on the timing of phenological phases (Cleland et al., 2007).

The objective of this paper is to provide a model-based assessment of the impact of projected climate change on sowing and harvest dates of spring barley and maize in Poland. The study looks into projected changes for two future time horizons within the 21st century (2021-2050 and 2071-2100) under the Representative Concentration Pathways (RCPs) 4.5 and 8.5, using an ensemble of nine bias-corrected EURO-CORDEX model scenarios. The Soil and Water Assessment Tool (SWAT) model incorporating the modified Erosion-Productivity Impact Calculator (EPIC) crop growth sub-model was used in this paper in order to analyse spatio-temporal variability in sowing and harvest dates.

(C) 2018 Institute of Agrophysics, Polish Academy of Sciences 


\section{MATERIALS AND METHODS}

This study is concentrated on the agricultural land within the Polish parts of two largest river basins in Poland, the Vistula and Odra basins (VOB), covering $87 \%$ of the Polish territory (Fig. 1). It investigates two important crops for Polish agriculture: spring barley and maize. Spring barley is the most common spring cereal in Poland. According to Agricultural Census Data (2002), spring cereals and maize accounted for $36 \%$ of cultivated area in Poland, of which, cereals occupied $31 \%$. Maize has undergone tremendous change in terms of cultivated area: in the interval from 1996 to 2015 , its area increased by an order of magnitude (from 69000 to $670000 \mathrm{ha}$ ). In this study, early ripening varieties of maize cultivated for silage were considered due to the lower risk of the loss of yield under the climatic conditions of Poland (Zaliwski and Hołaj, 2006).

SWAT is a process-based, continuous-time agro-hydrological model which simulates the movement of water on a catchment scale with a daily time step (Arnold et al., 1998). It integrates hydrological processes with the plant growth component based on a simplified version of the EPIC model (Williams et al., 1982). In EPIC, phenological plant development is based on daily accumulated heat units (growing degree days). In this study, we build upon the existing, extensively calibrated and validated SWAT model of the VOB (Piniewski et al., 2017).

In this study, SWAT model simulations were conducted in two steps. The first step included calibration and validation of the model as driven by interpolated meteorological data from the Polish and European monitoring network (Berezowski et al., 2016). In the second step, the climate projections data derived from Mezghani et al. (2017) were used as a forcing for both historical and future periods.

In SWAT, two different methods of agricultural operations scheduling are available. The first one is based on the Julian calendar and the model user has to define exact dates of each operation. The second method is based on heat unit theory (Bernard, 1948). This postulates that each

\section{A. Spring cereals $(31 \%)$}

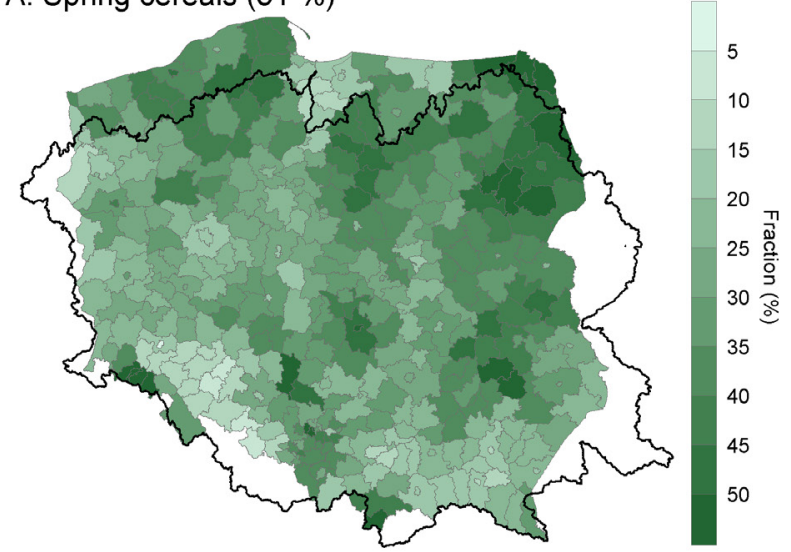

plant has its own temperature range for growth. Crop growth is triggered once the daily average temperature exceeds the crop-specific minimum temperature. The growth rate gradually increases with temperature until the maximum temperature is exceeded which ceases the growth. According to the theory, the timing of the operations are expressed as fractions of user-defined potential heat units $\left(\mathrm{PHU} / \mathrm{PHU}_{0}\right)$, which is the total number of heat units required for plant maturity. In this study, the heat unit method was used for agricultural operations scheduling.

Heat unit-based simulation of sowing and harvest dates in SWAT can be interpreted as an approximation of the corresponding phenological stages: beginning of growth and achieving crop maturity, respectively. The relationship between simulated dates and phenological phases is straightforward: crop emergence begins several days after sowing, whereas harvest takes place several days after reaching maturity. Projected changes in sowing dates can, therefore, be interpreted as proxies of changes in crop emergence, whereas changes in harvest dates act as proxies of changes in maturity.

In the current setup of the SWAT model created for the VOB, agricultural management calendars were defined for spring barley and maize (Piniewski et al., 2017). Base temperatures for heat unit calculation (T_BASE) were set to $5^{\circ} \mathrm{C}$ for spring barley and $8^{\circ} \mathrm{C}$ for maize, whereas the total number of heat units needed to bring plant to maturity (PHU_PLT) was set to 1230 for spring barley and 1200 for maize. In the heat unit method, the exact date of operation occurrence is varied from year to year, depending on the thermal conditions. Therefore, the crop-specific fraction of PHU and $\mathrm{PHU}_{0}$ for a particular operation needs to be adjusted iteratively until reasonable and satisfactory occurrence dates are achieved. In the VOB, the fraction index was assumed satisfactory when at least $75 \%$ of observed sowing and harvest dates fell into crop-specific optimal dates range resulting from literature review (Dragańska et al., 2008; Kruczek and Sulewska, 2005; Sułek, 2009).

\section{B. Maize (5\%)}

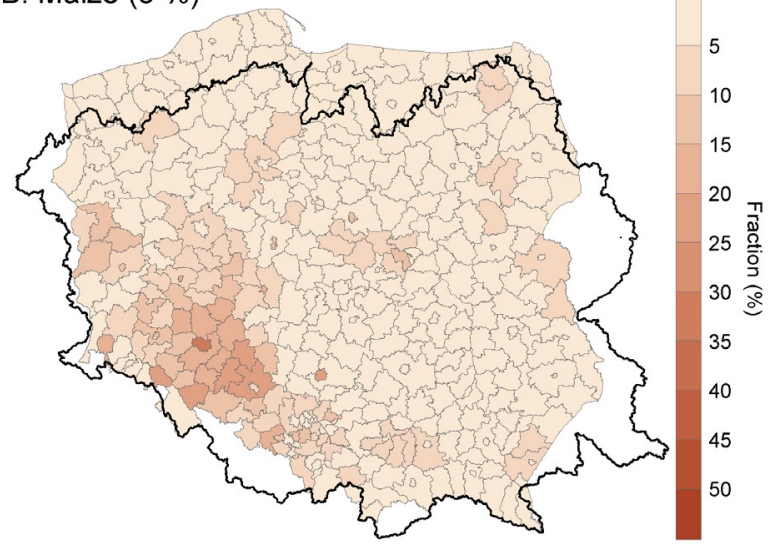

Fig. 1. Spatial distribution of selected crops in Poland (Agricultural Census, 2002) expressed as fractions of arable land cover at powiat level. Black line denotes the border of the Vistula and Odra basins.A - spring cereals, B - maize. 
In order to analyse the correlation between the pheonological phases and temperature, average temperature indices were calculated in a crop-specific and development stage-specific manner. For example, for spring barley, usually sown in March/April in Polish climatic conditions, a pre-sowing average temperature for February - April was calculated. Harvest of spring barley typically occurs in July/August, so that the average temperature was calculated for April - July. For maize, the temperatures were calculated for February - May (pre-sowing) and June October (pre-harvest).

In this paper, SWAT is driven by climate forcing data from the CHASE-PL Climate Projections: $5 \mathrm{~km}$ gridded daily precipitation and temperature dataset (CPLCP-GDPT5) (Mezghani et al., 2017), consisting of nine bias-corrected GCM-RCM runs provided within the EURO-CORDEX experiment projected to the year 2100 under two RCPs: 4.5 and 8.5. The RCPs are families of scenarios dependent on various assumptions about future socio-economic development and greenhouse gases concentrations (Moss et al., 2010). RCPs 4.5 and 8.5 correspond to two targeted radiative forcing levels in year 2100 relative to pre-industrial values: +4.5 and $+8.5 \mathrm{~W} \mathrm{~m}^{-2}$, respectively. These two RCPs were selected because they are the most commonly used in impact studies worldwide. A bias correction procedure was based on the quantile mapping method developed by the Norwegian Meteorological Institute (Gudmundsson et al., 2012), and it concerned three time periods: 1971-2000, 2021-2050, and 2071-2100. The corresponding time horizons will be hereafter referred to as historical period (ACT), near future (NF) and far future (FF), respectively. Future changes in planting and harvest dates were estimated as a difference (in days) between respective future periods and the historical (control) period. The model runs were carried out assuming constant land use, in order to illustrate pure climate change effect.

Projected mean annual temperature in Poland is expected to increase by approximately $1.1^{\circ} \mathrm{C}$ in $\mathrm{NF}$ and $2^{\circ} \mathrm{C}$ in FF following the RCP4.5 according to the ensemble mean. Comparing the seasonal variation, the highest change is expected to occur in winter $\left(2.5^{\circ} \mathrm{C}\right)$ and lowest in summer $\left(1.7^{\circ} \mathrm{C}\right)$. Following the RCP8.5 emission scenario, the temperature increase rate seem to accelerate substantially in the second half of the century, reaching on average $3.6^{\circ} \mathrm{C}$ in $\mathrm{FF}$, whereas in NF, it is quite similar to $\mathrm{RCP} 4.5\left(1.3^{\circ} \mathrm{C}\right.$ vs. $\left.1.1^{\circ} \mathrm{C}\right)$.

\section{RESULTS}

Area-averaged sowing and harvest timing variability is presented in box plots for each crop (Fig. 2A). The great majority of simulation results falls in the threshold ranges for both operations. In some cases, they go beyond the range, which is mainly caused by extremely cold and hot years, which explicitly determines either delay or accelera- tion of sowing and harvest. The lowest temporal variability in the occurrence of phenological phases, and, consequently, the highest accuracy of simulation is noted for spring barley. Slightly worse, but still satisfactory results were obtained for maize. It should be noted that other authors reported a very high inter-annual variability in maize maturity and harvest stages in Poland, reaching even 6 weeks in a 15-year long period (Dragańska et al., 2008). This supports a high variability in Fig. 2A (maize harvest date).

Spatial variability of sowing and harvest dates occurrence expressed as a mean value for the entire simulation period at sub-basin level is presented in Fig. 2B. In general terms, strong regionalisation of the occurrence of sowing dates with an increasing gradient towards the north-east is noted. It perfectly reflects the thermal conditions of Poland, where in the north-east, the temperatures are lower due to the influence of the continental climate and slightly higher in the west, conditioned by the milder maritime climate. The crop-specific range of the sowing dates across the country spans for 30 days and occurs earlier for spring barley (80-110) and significantly later for maize (110-140). Fairly similar trends are observed for the harvest which occur earlier in the south and south-western part of Poland and later in the north-eastern sub-basins. Regional differences in harvest dates, likewise for sowing, span for 30 days reaching ranges 210-240 and 230-260, for spring barley and maize, respectively, which is in accordance with general trends in literature.

Simulated multi-annual variability of area-averaged sowing and harvest dates strongly correlates with temperature ( $\mathrm{R}^{2}$ ranging from 0.7 to 0.9 ) (Fig. $2 \mathrm{C}$ and $\mathrm{D}$ ). High variability in the timing of sowing and harvest is visible, however, all fluctuations strongly follow thermal conditions of crop-specific critical period in a given year.

Climate change is expected to advance sowing operation of spring crops and harvest of the crops under consideration (Fig. 3). The rate of sowing acceleration is diverse and increases with the time horizon, reaching 4 days (NF) and 8 days (FF) for maize and 7 days (NF) to 16 days (FF) for spring barley under RCP4.5. With RCP8.5, the signal of change gets stronger and the acceleration of spring barley sowing dates increases to 9 days (NF) and 22 days (FF). For maize, the sowing advancement reaches 5 days and 10 days for NF and FF, respectively.

For harvest, the overall advance of its occurrence was noted for both crops. Likewise for sowing, the effect of climate change increases with both time horizon and RCP. For spring barley, under RCP4.5, the rate of acceleration reaches 8 days (NF) and 12 days (FF), whereas for maize - 13 days (NF) and 22 days (FF). The acceleration rate increases under RCP8.5, reaching 10 days (NF) and 23 days (FF) for spring barley, and 15 days (NF) and 30 days (FF) for maize.

Projected sowing and harvest dates of selected crops indicate clear regionalisation of sowing and harvest which follows the thermal conditions across the country (Fig. 4). 

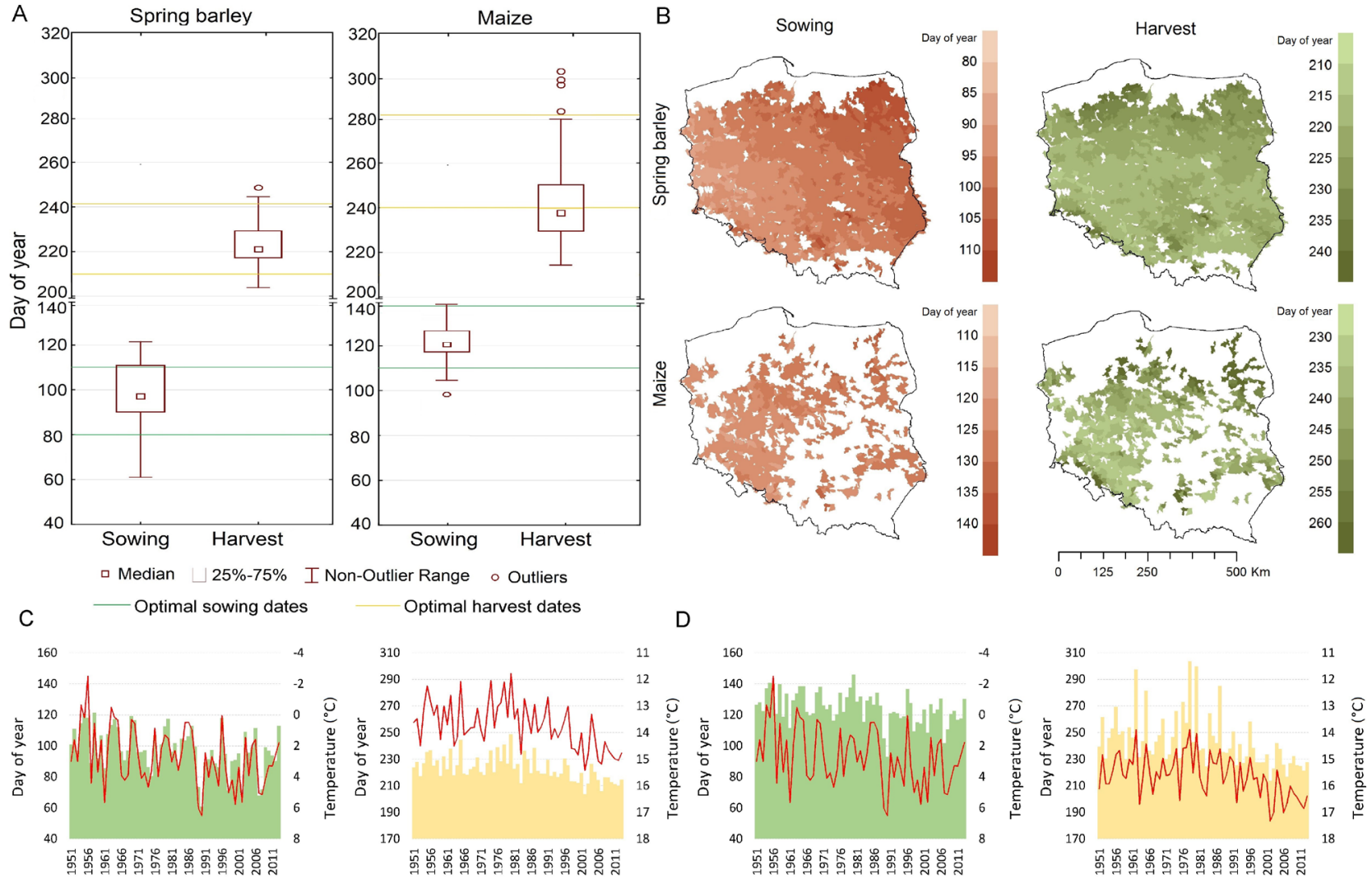

Fig. 2. Box plots of spatially-averaged simulated sowing and harvest dates of selected crops. Green and yellow lines in panel A represent optimal ranges of sowing and harvest dates in Polish conditions. B - Spatial distribution of multi-annual mean sowing and harvest dates. White spaces in panel B correspond to low fractions of a given crop in particular areas (sub-basins). Mean annual sowing (green) and harvest (yellow) dates of spring barley (C) and maize (D). Red lines in panels C and D show inter-annual variability in mean temperature for crop-specific pre-sowing and pre-harvest periods.

Sowing dates under RCP 4.5

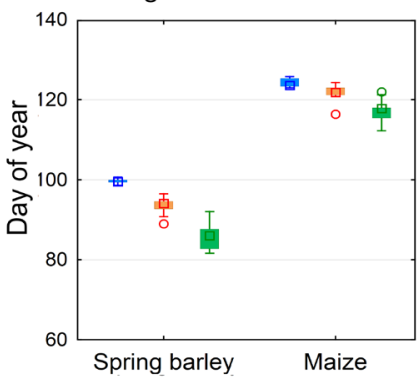

Sowing dates under RCP 8.5

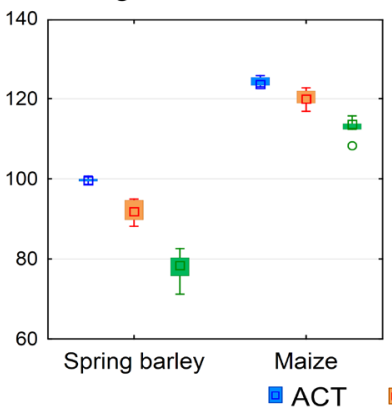

Harvest dates under RCP 4.5

Harvest dates under RCP 8.5
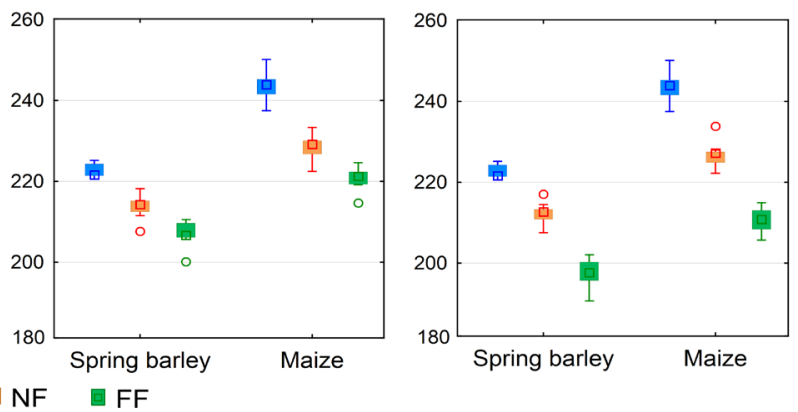

Fig. 3. Box plots of sowing and harvest dates for NF and FF under RCP4.5 and 8.5. Variability in box plots represents multi-annual mean dates of nine ensemble members.

There is a strong gradient increasing from south-west to north-east describing the sowing dates acceleration, and from south to north for harvest. The signal of change increases in magnitude with time horizon and RCP, but maintains the spatial pattern. The overall acceleration of sowing and harvest in each horizon-RCP combination is comparable to the mean values presented in the box plots in Fig. 3.

\section{DISCUSSION}

Simulated trends in sowing and harvest dates for the historical period in Poland are in line with studies reporting extension of the growing season and faster accumulation of the growing degree days (Graczyk and Kundzewicz, 2016; Wypych et al., 2017). A comparison of our results with similar studies reporting the impact of future climate 

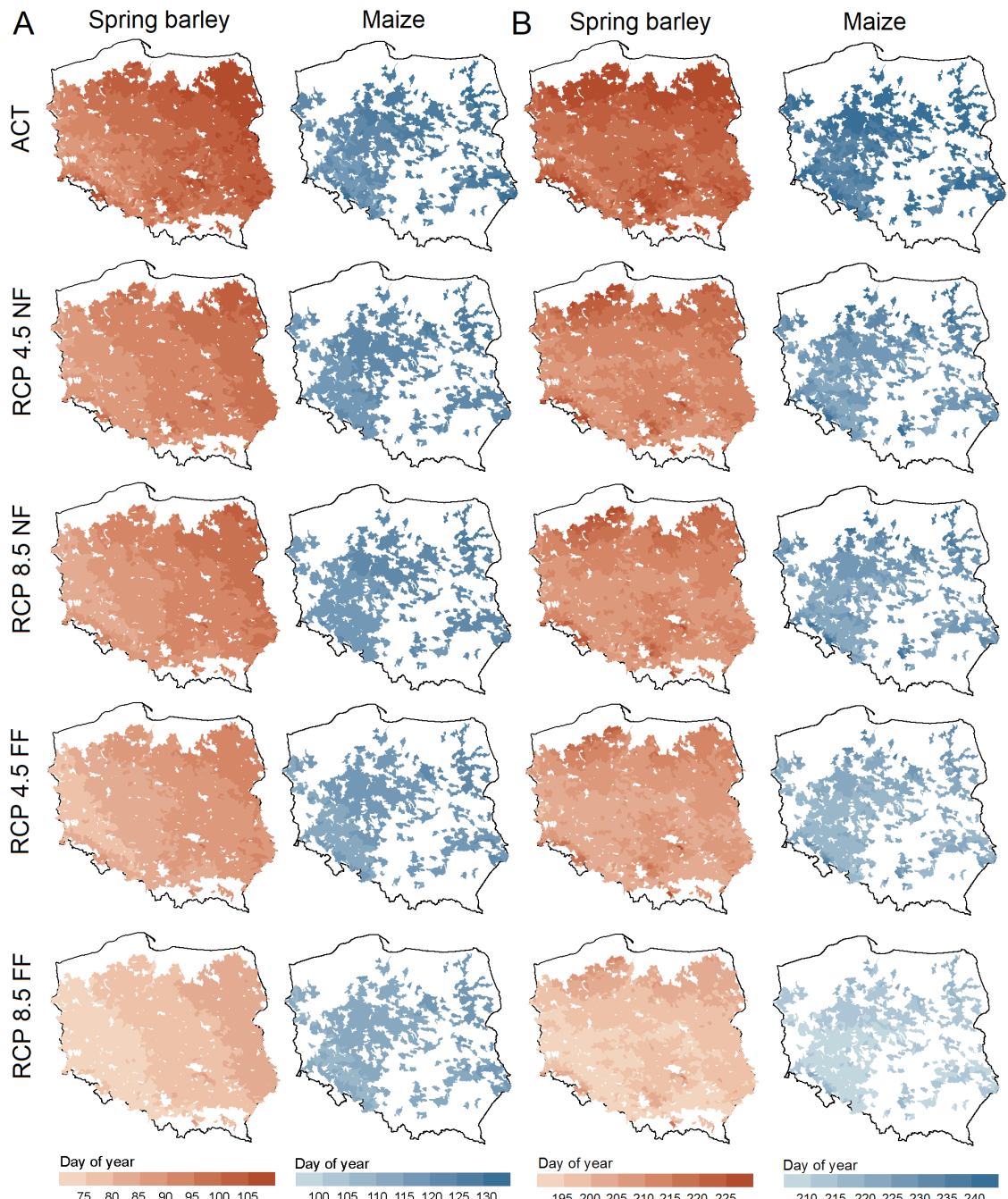

Day of year

100105110115120125130
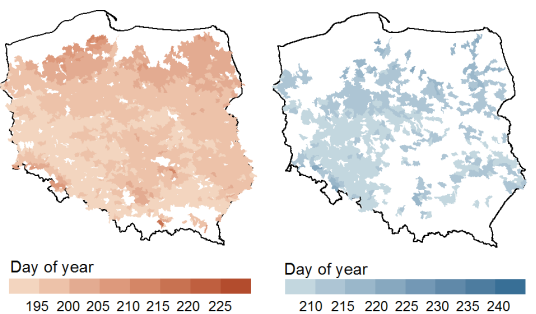

Day of year

210215220225230235240

Fig. 4. Spatial distribution of the multi-annual mean sowing (A) and harvest (B) dates for the historical period (Act) and two future horizons, NF and FF, under RCP4.5 and 8.5, according to the ensemble mean. White spaces correspond to low fractions of a given crop in particular areas.

change on sowing and harvest dates is more difficult, however, as in every study different climate models, emission scenarios and time horizons are usually used. Olesen et al. (2012) investigated the impact of climate change on oats and maize using a statistical model driven by the ECHAM5 climate model under the A1B emission scenario for the years 2031-2050. The predicted advancement of sowing and harvest dates for Poland for this scenario was, in their study, in good agreement with the corresponding RCP8.5 NF scenario in our study. What is noteworthy, in both studies, fairly similar spatial variation of the sowing/harvest dates occurrence was noted, characterised by a clearly increasing gradient from south-west towards north-east. Rötter et al. (2011) conducted a similar study for spring barley in Finland, using the WOFOST model as driven by two emission scenarios: B1 and A1F1, for the years 20712100. They noted an acceleration of sowing dates reaching 14 days (B1) and 22 days (A1F1), which also corroborates our findings for corresponding scenarios RCP4.5 FF and RCP8.5 FF, respectively. Although our projections are in line with literature, the added value of our study is a higher spatial resolution, the use of a more recent emission scenario family (RCP instead of SRES) and a larger ensemble of climate models (nine instead of one and two in aforementioned studies).

Projections of changes in sowing and harvest dates in response to climate change are extremely important in the planning of agricultural production and adaptation and mitigation strategy (Kozyra, 2013). Significant shifts in the beginning and duration of growing season might significantly affect crop yields (Rötter et al., 2011). For example, Parker et al. (2016) reported that earlier sowing of maize in Germany under warming conditions might result in greater yielding due to extended growing period. On the other hand, Eitzinger et al. (2013) revealed that yields are expected to decrease under climate change in Central and Eastern 
Europe if there is no adaptation strategy applied. They pointed out that adaptation should be related to altered production techniques that affect the water balance/demand of crops, the effective use of soil and water resources and the adapted crop timing and selection. Actually, adaptation of timing of management practices by farmers has already been noted in Poland (Blecharczyk et al., 2016). In general, since the expected future dynamics of changes in agroclimatic indices in Central and Eastern Europe is going to be very high, continuous, adaptive management should be a way forward (Trnka et al., 2009).

Among the several limitations of this study, one has to note that the applied model does not take into consideration precipitation conditions suitable for management operations (Eitzinger et al., 2013). Moisture conditions from the practical crop-cultivation point of view can significantly affect the start of sowing and harvest. Even if the thermal conditions were favourable for sowing, too wet soils might indispose entering tractors into the field to start the operation. Since future precipitation projections for Poland show high increases in spring (Mezghani et al., 2017), it is likely that performing sowing operation by farmers 2 or 3 weeks earlier than at present might be difficult or even impossible due to excessive moisture.

\section{CONCLUSIONS}

1. The analysing of historical patterns and model simulations correctly reflect the fluctuations of air temperature, showing high correlation between the sowing/harvest dates and crop-specific mean temperature of pre-sowing and preharvest periods.

2. Spatial variation was accurately reflected, showing delayed sowing/harvest in colder regions (north-east) and advanced sowing/harvest in warmer parts of the country (south-west).

3. Projected warmer climate significantly affected potential scheduling of agricultural practices, accelerating the occurrence of sowing and harvest dates. The rate of acceleration was dependent on the time horizon and representative concentration pathway scenario.

4. The rate of sowing/harvest advance was increasing from near future to far future and also from representative concentration pathway 4.5 to 8.5 . The highest advancement was projected for far future under representative concentration pathway 8.5 , reaching 23 and 30 days for spring barley and maize, respectively.

5. Spatially, future projections are fairly similar with the historical pattern, indicating congruous regionalisation with delayed (north-east) and advanced (south-west) sowing/harvest areas.

Conflict of interest: The Authors do not declare conflict of interest.

\section{REFERENCES}

Albiac J., Kahil T., Notivol E., and Calvo E., 2017. Agriculture and climate change: Potential for mitigation in Spain. Science of The Total Environment, 592(15), 495-502.

Arnold J.G., Srinivasan R., Muttiah R.S., and Williams J.R., 1998. Large area hydrologic modeling and assessment part I: Model development. J. American Water Res. Association, 34, 73-89.

Berezowski T., Szcześniak M., Kardel I., Michałowski R., Okruszko T., Mezghani A., and Piniewski M., 2016. CPLFD-GDPT5: High-resolution gridded daily precipitation and temperature data set for two largest Polish river basins. Earth Syst. Sci. Data, 8, 127-139.

Bernard J.D., 1948. Heat units as a measure of canning crop maturity. The Canner, 106, 28.

Blecharczyk A., Sawinska Z., Malecka I., Sparks T.H., and Tryjanowski P., 2016. The phenology of winter rye in Poland: an analysis of long-term experimental data. Int. J. Biometeorol., 60(9), 1341-1346.

Cleland E.E., Chuine I., Menzel A., Mooney H.A., and Schwartz M.D., 2007. Shifting plant phenology in response to global change. Trends in Ecology Evolution, 22(7), 357-365.

Dragańska E., Szwejkowski Z., and Panfil M., 2008. Yield of corn cultivated for grain in wielkopolska region predicted in regard to expected climate changes. Acta Agrophysica, 12(3), 645-655.

Duchêne E. and Schneider C., 2005. Grapevine and climatic changes: a glance at the situation in Alsace. Agron Sustain Dev., 25, 93-99.

Eitzinger J., Trnka M., Semerádová D., Thaler S., Svobodová E., Hlavinka P., Šiška B., Takác J., Malatinská L., Nováková M., Dubrovský M., and Žalud Z., 2013. Regional climate change impacts on agricultural crop production in Central and Eastern Europe - hotspots, regional differences and common trends. The J. Agricultural Sci., 151(6), 787-812.

Gil J.D.B., Cohn A.S., Duncan J., Newton P., and Vermeulen S., 2017. The resilience of integrated agricultural systems to climate change. WIREs Clim Change, 8: n/a, e461. doi:10.1002/wcc.461

Glavan M., Ceglar A., and Pintar M., 2015. Assessing the impacts of climate change on water quantity and quality modelling in small Slovenian Mediterranean catchment lesson for policy and decision makers. Hydrological Proc., 29(14), 3124-3144.

Graczyk D. and Kundzewicz Z.W., 2016. Changes of temperature-related agroclimatic indices in Poland. Theoretical and Applied Climatology, 124(1-2), 401-410.

Gudmundsson L., Bremnes J.B., Haugen J.E., and EngenSkaugen T., 2012. Technical Note: Downscaling RCM precipitation to the station scale using statistical transformations - a comparison of methods, Hydrol. Earth Syst. Sci., 16, 3383-3390, doi:10.5194/hess-16-3383-2012

Kozyra J., 2013. Impact of projected air temperature change on winter cereals phenology in Poland (in Polish). Institute of Soil Science and Plant Cultivation State Research Institute, Puławy, Poland. 
Kruczek A. and Sulewska H., 2005. Effect of method of fertilization, term of sowing and varieties on accumulation of mineral components by maize in initial stage of development (in Polish). Acta Agrophysica, 5(3), 683-694.

Lipiec J., Doussan C., Nosalewicz A., and Kondracka K., 2013. Effect of drought and heat stresses on plant growth and yield: a review. Int. Agrophys., 27(4), 463-477.

Ma S., Churkina G., and Trusilova K., 2012. Investigating the impact of climate change on crop phenological events in Europe with a phenology model. Int. J. Biometeorol., 56, 749-763.

Marcinkowski P., Piniewski M., Kardel I., Szcześniak M., Benestad M., Srinivasan R., Ignar S., and Okruszko T., 2017. Effect of climate change on hydrology, sediment and nutrient losses in two lowland catchments in Poland. Water, 9(3), 156, doi:10.3390/w9030156

Menzel A., 2000. Trends in phenological phases in Europe between 1951 and 1996. Int. J. Biometeorol., 44, 76-81.

Menzel A., 2006. European phenological response to climate change matches the warming pattern. Glob. Chang. Biol., 12, 1969-1976.

Mezghani A., Dobler A., Haugen J.E., Benestad R.E., Parding K.M., Piniewski M., Kardel I., and Kundzewicz Z.W., 2017. CHASE-PL Climate Projection dataset over Poland - Bias adjustment of EURO-CORDEX simulations, Earth Syst. Sci. Data Discuss., https://doi.org/10.5194/ essd-2017-51

Moss R.H., Edmonds J.A., Hibbard K.A., Manning M.R., Rose S.K., van Vuuren D.P., Carter T.R., Emori S., Kainuma M., Kram T., Meehl G.A., Mitchell J.F.B., Nakicenovic N., Riahi K., Smith S.J., Stouffer R.J., Thomson A.M., Weyant J.P., and Wilbanks T.J., 2010. The next generation of scenarios for climate change research and assessment. Nature, 463, 747-756, doi:10.1038/nature08823

Møller L.R., Drews M., and Larsen M.A.D., 2017. Simulation of optimal decision-making under the impacts of climate change. Environ. Manag., 60, 104, doi:10.1007/s00267017-0852-1

Olesen J.E. and Bindi M., 2002. Consequences of climate change for European agricultural productivity, land use and policy. Eur J Agron., 16, 239-262.

Olesen J.E., Børgesen C.D., Elsgaard L., Palosuo T., Rötter R.P., Skjelvåg A.O., Peltonen-Sainio P., Börjesson T.,
Trnka M., Ewert F., and Siebert S., 2012. Changes in time of sowing, flowering and maturity of cereals in Europe under climate change. Food Additives Contaminants: Part A, 29(10), 1527-1542.

Parker P. S., Shonkwiler J. S., and Aurbacher J., 2017. Cause and Consequence in Maize Planting Dates in Germany. J.Agro. Crop. Sci., 203, 227-240, doi:10.1111/jac.12182

Piniewski M., Szcześniak M., Kardel I., Berezowski T., Okruszko T., Srinivasan R., Vikhamar-Schuler D., and Kundzewicz Z.W., 2017. Hydrological modelling of the Vistula and Odra river basins using SWAT. Hydrol. Sci. J., 62(8), 1266-1289.

Rötter R.P., Palosuo T., Pirttioja N.K., Dubrovsky M., Salo T., Fronzek S., Aikasalo R., Trnka M., Ristolainen A., and Carter T.R., 2011. What would happen to barley production in Finland if global warming exceeded $4^{\circ} \mathrm{C}$ ? A model-based assessment. Eur. J. Agronomy, 35, 205-214.

Sadras V.O., Monz J.P., 2006. Modelled wheat phenology captures rising temperature trends: Shortened time to flowering and maturity in Australia and Argentina. Field Crops Res., 99, 136-146.

Sulek A., 2009. Influence of sowing and harvest date on grain yield and protein content in grain of spring wheat $c v$. Nawra (in Polish). Fragm. Agron., 26(2), 138-14.

Trnka M., Eitzinger J., Hlavinka P., Dubrovský M., Semerádová D., Štěpánek P., Thaler S., Žalud Z., Možný M., and Formayer H., 2009. Climate-driven changes of production regions in Central Europe. Plant Soil Environ., $55,257-266$.

Williams J.R., Renard K.G., and Dyke P.T., 1982. EPIC a new model for assessing erosion's effect on soil productivity. J. Soil Water Conserv., 38(5), 381-383.

Wolfe D.W., Schwartz M.D., Lakso A.N., Otsuki Y., Pool R.M., and Shaulis N.J., 2005. Climate change and shifts in spring phenology of three horticultural woody perennials in northeastern USA. Int. J. Biometeorol., 49, 303-309.

Wypych A., Sulikowska A., Ustrnul Z., and Czekierda D., 2017. Variability of growing degree days in Poland in response to ongoing climate changes in Europe. Int. J. Biometeorol., 61(1), 49-59.

Zaliwski A.S. and Hołaj J., 2006. Modelling of grain maize production technology in the aspect of economic effectiveness. Inżynieria Rolnicza, 6(81), 407-414. 